\title{
Trends in the job market of nurses in the view of managers
}

\author{
Tendências do mercado de trabalho de enfermeiros/as na visão de gestores \\ Tendencias del mercado de trabajo de enfermeros/as en la visión de gestores
}

\section{Jonas Sâmi Albuquerque de Oliveira', Denise Elvira Pires de Pires', Ângela Maria Alvarez", Roseni Rosângela de Sena"I, Soraya Maria de Medeiros ${ }^{\text {IV }}$, Selma Regina de Andrade"}
' Universidade Federal de Santa Catarina, Postgraduate Program in Nursing. Florianópolis, Santa Catarina, Brazil.
"Universidade Federal de Santa Catarina, Health Sciences Center, Department of Nursing. Florianópolis, Santa Catarina, Brazil.
I' Universidade Federal de Minas Gerais, Nursing school, Department of Maternal and Child Nursing and Public Health. Belo Horizonte, Minas Gerais, Brazil.
Iv Universidade Federal do Rio Grande do Norte, Center for Health Sciences, Department of Nursing. Natal, Rio Grande do Norte, Brazil.

How to cite this article:

Oliveira JSA, Pires DEP, Alvarez AM, Sena RR, Medeiros SM, Andrade SR. Trends in the job market of nurses in the view of managers. Rev Bras Enferm [Internet]. 2018;71(1):148-55. DOI: http://dx.doi.org/10.1590/0034-7167-2016-0103

\section{ABSTRACT}

Objective: to identify and interpret the main trends of the labor market for nurses in Rio Grande do Norte, based on the opinion of managers of training institutions and employers. Method: Data were collected through interviews with key informants, organized using Atlas.ti software resources and examined under the thematic content review. Results: the study showed six trends in the labor market of nurses: availability of professionals to the market; worsening working conditions with precariousness; indication for insertion in employment; unemployment for nurses; shortage of nurses; and the existence of a cooperative of nursing professionals. Final considerations: the current scenario of growth in the number of registered nurses without the expansion of the job supply has remained, unemployment tends to increase and work conditions will worsen.

Descriptors: Labor Market; Nurse; Unemployment; Health Manager; Employment.

\section{RESUMO}

Objetivo: identificar e interpretar as principais tendências do mercado de trabalho para os/as enfermeiros/as no Rio Grande do Norte, a partir da opinião de gestores de instituições formadoras e empregadoras. Método: os dados foram coletados através de entrevistas com informantes-chave, organizados por meio dos recursos do software Atlas.ti e examinados sob o olhar da análise de conteúdo temática. Resultados: o estudo mostrou seis tendências no mercado de trabalho dos/as enfermeiros/as: disponibilidade de profissionais para o mercado; piora nas condições de trabalho com precarização; indicação para inserção no emprego; desemprego para enfermeiros; escassez de enfermeiros/as; e existência de cooperativa de profissionais de enfermagem. Considerações finais: mantido o cenário atual de crescimento do número de enfermeiros/as titulados/as sem expansão da oferta de postos de trabalho, o desemprego tende a crescer e as condições de trabalho a se agravar.

Descritores: Mercado de Trabalho; Enfermeiro; Desemprego; Gestor de Saúde; Emprego.

\section{RESUMEN}

Objetivo: identificar e interpretar las principales tendencias del mercado de trabajo para los/las enfermeros/as en Rio Grande do Norte, a partir de la opinión de gestores de instituciones formadoras y empleadoras. Método: los datos fueron colectados a través de entrevistas con informantes-llave, organizados por medio de los recursos de software Atlas.ti y examinados bajo la mirada del análisis de contenido temático. Resultados: el estudio señaló seis tendencias en el mercado de trabajo de los/las enfermeros/ as: disponibilidad de profesionales para el mercado; empeora en las condiciones de trabajo con precarización; indicación para inserción en el empleo; desempleo para enfermeros; escasez de enfermeros/as; y existencia de cooperativa de profesionales de 
enfermería. Consideraciones finales: mantenido el escenario actual de crecimiento del número de enfermeros/as titulados/as sin expansión de oferta de puestos de trabajo, el desempleo tiende a crecer y las condiciones de trabajo a agravarse.

Descriptores: Mercado de Trabajo; Enfermero; Desempleo; Gestor de Salud; Empleo.

\section{CORRESPONDING AUTHOR}

\section{INTRODUCTION}

The discussion about the labor market is an important theme in the international scenario, visible in publications in several areas, with a predominance in sociology and economics. There is a relationship between the labor market and the economic and political scenario of the various countries.

Considering the dynamics of the labor market, at the international level, there is a paradox. On the one hand, there is a numerical deficit of health professionals, such as nursing, to meet health and education / training needs. On the other hand, there are countries and regions where there is unemployment, as well as migration in search of better working conditions ${ }^{(1)}$.

Studies in the Organization for Economic Co-operation and Development (OECD) countries show that crisis scenarios interfere with health sector financing and promote changes in the dynamics of the labor market. However, there is no economic determinism, the results depend on the interrelation of several factors, among them the State policies adopted by the countries, resulting in different market trends for health professionals, including nurses ${ }^{(2)}$.

From the list of trends observed in the literature on the labor market of nurses around the world, a complex picture is identified that associates unemployment and underemployment with the shortage of skilled nurses.

With regard to unemployment, the availability of young nurses who are unemployed is associated with the unemployment of experienced nurses who were excluded from the labor market in times of crisis. Underemployment and poor working conditions affect those who remain in the market and also encourage the exit of the profession, that is, the decision not to work for the salaries offered and under other unfavorable conditions ${ }^{(3-6)}$.

Economic imbalances generate budget cuts and encourage the public and private sectors to take measures to reduce production costs, including the health field and the labor market of nurses. Competitive pressure leads capital to reduce costs many times by reducing jobs and using the automation feature; however, this does not apply to the workforce of nurses who perform essential, indispensable and difficult labor replacement by machines ${ }^{(7-8)}$.

However, the literature also shows concern about the lack of replacement of qualified nurses, which is a scarcity of these professionals. This phenomenon is related to the aging of nurses, with a consequent tendency to abandon the labor market due to retirement ${ }^{(9)}$.

In relation to nursing jobs in the Brazilian reality, historical and political factors help to understand the current scenario. The creation of the Unified Health System (SUS) by the Brazilian Constitution of 1988, the adoption of Law 8080 of 1990 and the adoption of policies to expand basic health care and incorporate the Family Health Strategy (ESF) as a care model resulted in changes in the health work market with a view to guaranteeing universal and continuous access to health services, with quality and resolubility. In this scenario, there was an increase in the number of jobs for nurses, especially in family health ${ }^{(10)}$.

Several other factors in the health field explain the need for a workforce to meet local and regional demands. These include the demographic transition, the aging of the population, the prolonged epidemiological transition, characterized by the persistence of Transmissible Diseases (TD), the emergence of new endemic diseases and epidemics, the increase in Chronic Non-communicable Diseases (CDNT) and significant increase in damages and deaths from external causes ${ }^{(11)}$.

The data show that employment for nurses has been increasing in the country. The Institute of Applied Economic Research (IPEA) showed that 'nurses and the like' ranked second among the careers that grew the most in number of jobs between January 2009 and December 2012. And the Annual Social Information Report (RAIS) of the Ministry of Labor and Employment (MTE) records that nineteen Brazilian states and the Federal District (DF) presented positive growth in the number of ties to 'nurses and the like' in the period from 2009 to 2013. Only in seven states (Rio Grande do Norte, Sergipe, Rio Grande do Sul, Mato Grosso do Sul, Amazonas, Amapá and Tocantins) did the oscillations (increase / decrease or growth / decrease / growth) (Growth / decrease or growth / decrease / growth) of the labor ties of these professionals in that period ${ }^{(12)}$.

In this context it is possible to make several questions about the labor market trends for nurses in the state of Rio Grande do Norte. Given the current scenario of training and absorption of the workforce of nurses in the RN, how do the managers of Higher Education Institutions (HEls) and employers perceive the market for these professionals? What trends are verified? In this context, the present study aimed to identify and interpret the main trends of the labor market for nurses in Rio Grande do Norte, from the perspective of managers of training institutions and employers.

\section{METHOD}

\section{Ethical aspects}

The research project was submitted to the Committee of Ethics in Research with Human Beings of the State University of Santa Catarina, and the opinion was approved. During the data collection process, the consent of the participants and signing of the Informed Consent Term (TCLE) were requested, following the norms of Resolution 466/12, which deals with the Guidelines and Norms Regulating Research involving Human Beings. In order to guarantee identity confidentiality, the names of the participants were replaced by the pseudonym manager, followed by the Arabic number chosen by the order of the interview. The managers of higher education institutions were presented as (GIES 1-9), those of the technical schools, such as (GET 1-3), those of hospitals, $(\mathrm{GH} 1-3)$, the cooperative of nursing professionals, as (GC 1), the 
Municipal Health Department of Natal (GSMN 1) and those of the State Department of Health (GSES 1-2).

\section{Kind of study}

Qualitative approach research with higher education managers in nursing and employers of nurses from public and private institutions in the state of Rio Grande do Norte, Brazil. Intentional sampling was used, considering as inclusion criteria: leadership in the training of nurses and large employers in the public and private sectors.

As exclusion criteria, small employers with fragmented distribution in the state, which would make access difficult (the majority of primary care employers - municipal managers) are included in this criterion. This criterion was not considered as limiting the study, since it can not be affirmed that there was an increase of nurses in the FHT, through public tenders in the State during the period of the research. It is noteworthy that only $25 \%$ of the vacancies of the calls for tenders from 2009 to 2013 were offered for the composition of the teams in this area in the State. It is also emphasized that the capital, responsible for the employability of more than $80 \%$ of the nurses in the ESF, has not offered a public tender for these professionals for more than ten years, with the purpose of replacing and expanding the Family Health teams.

\section{Study scenario and data source}

The sample included the coordination of colleges and universities that train nurses in the State, as well as the managers of the Municipal Health Secretariat of Natal (coordination of basic care) and the State Health Secretariat of Rio Grande do Norte (Secretary of Health and coordination of human resources). By employing nurses in the teaching modality of the nursing technical courses, the directions of the nursing technical courses of the capital were included. Also participated the technical responsible for the nursing cooperative of the state and managers of nursing of private hospitals of the capital.

Figure 1 corresponds to a representative network or network of managers of the institutions that participated in the study, elaborated using Atlas.ti 7.0 (Qualitative Research and Solutions) software.

\section{Collection and organization of data}

Data collection was performed between December 2014 and March 2015, totaling 19 participants and 9 hours and 44 minutes of recording. For data collection, the semi-structured interview technique was used. This type of interview is carried out following a script previously elaborated and used by the researcher with a view to contributing to a safe approach that the presuppositions are contemplated in the conversation ${ }^{(13)}$.

The interviews were carried out in the work place of the managers, previously scheduled by phone, according to the availability of those. The interviews were recorded and transcribed by the researcher. The data were organized and coded using the software for qualitative analysis, Atlas.ti 7.0 software (Qualitative Research and Solutions).

In the material exploration stage, the information contained in the material was encoded in order to reach the text sense nucleus; Thus quotations or quotations were made, citations of the primary documents, that is, in the case of this research in particular, were selected fragments of the speeches of the participants. After the quotations were assigned the codes, represented by the codification, by typing by a word or a set of words of each quotation, pre-established in the pre-analysis.

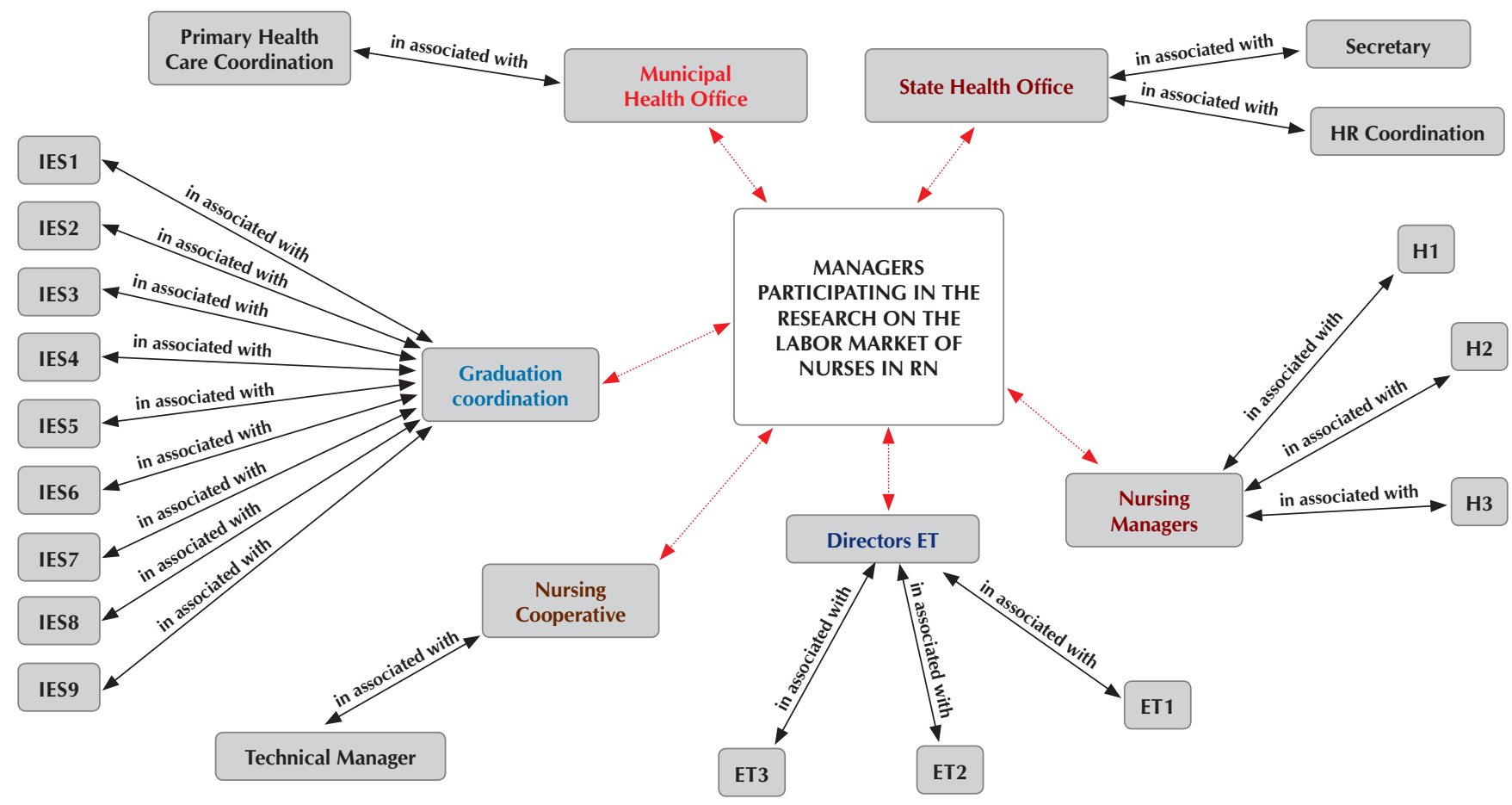

Figure 1 - Managers of the institutions that participated in the study, Rio Grande do Norte, Brazil, 2015 
Finally, these codes were classified into thematic categories (families), which are the sets of primary documents, codes or memos grouped by convenience or by theoretical proximity. In this study, axes 1 and 2 were adopted, such as families, which represent the unfavorable and favorable trends of the labor market for nurses in the state of Rio Grande do Norte from the perspective of managers. In the treatment of results and interpretation, 'the analyst, having at his disposal significant and faithful results, can then propose inferences and advance interpretations in relation to the intended objectives, or other unexpected discoveries ${ }^{\prime(14)}$.

In this stage, the software assisted in the organization of visualization networks of the main results that were interpreted, taking as support the sociological theorization available on the labor market in health and nursing.

\section{Data analysis}

The evaluation of the data followed the Analysis of Thematic Content and guided by the sociological approach of the labor market ${ }^{(14)}$. The reports of managers and employers about the trends of the labor market for nurses in the NB were systematized according to the main information present in the interviewees' speeches, seeking to identify the most significant themes that represent trends in the labor market of the nurses. The various trends were grouped according to the similarities.

Thematic analysis is one of the forms that best fits qualitative research and is composed of three stages. The first, called pre-analysis, consists of an activity known as 'floating reading' of interviews and transcribed observations, with the purpose of generating initial impressions about the material to be analyzed ${ }^{(14)}$; at that time the selection and organization of the data was done with the aid of Atlas.ti 7.0 software.

\section{RESULTS}

The key informants who participated in the survey are all nurses, with a predominance of females (13) and three males. All reported having management experience. Regarding the time as manager in that institution, it ranged from less than a year to more than five years, with a predominance of one to five years of experience.

The results were presented in descriptive form, in two macro-categories of analysis. The first, called Axis 1 - Unfavorable trends for the insertion of nurses in the labor market; the second, Axis 2 - Favorable trends for the insertion of nurses in the labor market.

\section{Axis 1: Unfavorable trends for the insertion of nurses in the labor market}

\section{Availability of professionals for the market}

Among the unfavorable trends, the existence of a considerable number of nurses available to the market and who did not find employment was identified. The causes of this situation, according to the participants of the research, are due to the increase in the number of undergraduate courses and graduates in nursing in a scenario of reduction of vacancies by employers.
The availability of nurses to the labor market in the RN increased due to the growth in the number of undergraduate courses, vacancies and HEIs in the state. When referring to the influence of the number of HEls, courses and vacancies in the labor market for nurses, the managers reported:

Nurses are no longer professional professionals. We have many professionals in the market for the number of insufficient vacancies to attend to all this demand. (G IES 4)

A more competitive and selective job market in the insertion of nurses in the area, adding to the high number of professionals available and the absence of jobs for this contingent generates a significant number of nurses who have completed graduation and are, due to lack of opportunity, without put on the market. This can be seen in the following speech:

So there are no vacancies in the job market for nurses. There is a very large number of professionals that are not working in the field of training. (G IES 4)

In the context of the labor market of the nurses of the state of Rio Grande do Norte there is already a significant number of professionals who have completed the undergraduate course and do not work in the area of their training.

\section{Worsening working conditions with precarious conditions}

The worsening of precarious working conditions was identified as a labor market trend due to the absence of job security, temporary contracts and different impacts on compensation.

The trend of precariousness in the labor market in the area has been described in several ways. First, in the form of hiring of the nurses for a fixed time, which puts them in a less favorable situation in relation to the labor rights enjoyed by colleagues with regular contracts.

Nurses are hired for practice hours and have no ties to the school. Some are already registered nurses, there you do not even need it. (GET2)

The tendency of precariousness was also verified in private hospitals. Employers, to meet the need for specialists, hire nurses as "service providers" for a fixed time.

Concerning the worsening of working conditions, the study mentioned the stagnation or reduction of wages, which in many situations is triggered by the contingent of workers available in the market, as illustrated by the following statements:

\begin{abstract}
And today, 2014, I talk to my colleagues who are working as nursing assistants, and comparing the amount I received at the first institution that I worked as a nurse in 2005, she told me that there was no change in the pay gap, it's a damn stagnation! This nurse told me that she is looking for something better, but the market is saturated, and if she says she wants to earn more, the institution has a box full of resumes wanting the vacancy, waiting for this vacancy ... (GIES 3)
\end{abstract}

The professional category has already been influenced by the availability of work force in the profession, which has been 
causing maintenance and / or reduction of the salary values perceived by those who are employed or seeking a job.

\section{Indication for insertion into employment}

The implications and influences of the trend "indication to a job vacancy", presented in figure 4, articulate: the mode of hiring in private hospitals; the quality of the workforce available; the insertion in the labor market within the state of professionals graduating from colleges with campuses in the interior; and discouragement.

One thing here is that some health care institutions try to get us to indicate the students, sometimes it happens that they want students from here. (G IES 1)

$50 \%$ of the students have already been able to enter the labor market in the interior, but practically all by indication in their interior [city of origin]. It was important to create a camp site in the interior, it was important to meet the need. (G IES 4)

It is noticeable the practice of insertion in the labor market of nurses who do not meet the criteria of equality and merit selection rights.

\section{Unemployment for nurses}

Unemployment was revealed as a trend that has been generating discouragement with the area, seeking the academic master's degree as a form of access to some remuneration and great demand for employment in the training institutions themselves. The main causes of unemployment are the increase in the number of nurses available in the market, due to the growth of graduates in schools, in a scenario of reduction of the supply of jobs by employers.

In fact I get daily resumes here from professionals who have not been acting for more than two years. $(\mathrm{G} \mathrm{H} 3)$

I have many resumes, it's a question of piles, lots of boxes. I'm saying it's five a day at a minimum. Unfortunately we look at some, others do not even look, because we can not hire them. Only if someone asks for a resignation, just like that, you know, because with a signed handbook, you can not ... (GET 3)

Unemployment for nurses is a trend in the state of Rio Grande do Norte, especially for professionals intending to enter the profession, especially young people with no professional experience.

\section{Axis 2 - Favorable trends for the insertion of nurses in the} labor market

\section{Scarcity of nurses}

Although there are nurses looking for a job in the NB, there are vacancies available, especially in private hospitals, which are not filled by the lack of qualified professionals to perform these functions, mainly due to lack of experience. Also identified was the shortage of specialized workforce with experience in health management.
Today you already have specialists in transplants, wounds, urgency and emergency, ICU and that already provides better quality in the assistance. But there is a shortage of more specialists to improve the care provided. (GSES 1)

Most curricula have specialization, but no practice. In a month, if I get forty resumes, two you have how to save for a selection ... I have a resume file, and I select it by practical experience. I understand that the academic experience is important in the formation, of undoubted relevance, but in the day to day of the assistance, you need the practical experience, something that is not easy. $(\mathrm{H} 1)$

Problems arise in the formation of "new" nurses, especially regarding technical skills and the fundamental requirement of higher education in the area that is the role of health and care management.

\section{Cooperative of nursing professionals}

The cooperative constituted with the purpose of intermediation in the hiring of labor force was pointed out as a trend in the job market for nurses in the RN.

The cooperative of nursing professionals was pointed out as a space for the insertion of nurses in the labor market in an autonomous way. In the RN there are still few professionals who have adhered to this modality of work. In this, the professionals do not have employment relationship and perceive remuneration compatible with the exercise of hours worked, as they are autonomous, as exemplified in the following lines:

In the cooperative we are autonomous professionals, we exercise the cooperation in the $R N$ and we receive by the production of each one. Who produces produces and the opposite does not. It is a mode of professional exercise as autonomous nurses. (GCE 1)

The number of nurses' cooperatives is still small; however, this modality of work was identified as a market trend in the state.

\section{DISCUSSION}

The topic of nursing work market has been the subject of current concern of scholars worldwide, especially in developed countries. The analysis of the interviews carried out with the managers that work in the scope of the training and the hiring of the nurses in the RN showed that there is a relation between the scenario of transformations in the formation in nursing in the state, with the growth of the installation of private companies of higher education and the high availability of nurses' workforce in the area.

There was a predominance of unfavorable tendencies for the labor market of nurses in the study state. One of them is the significant number of available labor force generating difficulties for the insertion in the job, discouragement, the subjection to jobs in precarious / unfavorable conditions, the search of scholarships in the postgraduate like form of remuneration.

The difficulty of access to employment is intensifying, evidenced by the increase in the time that the graduates take in the search of a placement in the market, which reaches more than two years in this course. The availability of professionals 
or 'reserve army' is an important marker in the job market of the profession in the RN.

Regarding waiting time for labor market insertion or job search, other studies performed in Brazil showed a more positive reality, with a waiting time of up to three months prevailing. Study of the waiting time for the insertion in the labor market of graduate nursing graduates from a public university in the southeast of the country found, among 175 graduates of the course, from 2000 to 2005 , that $45.1 \%$ took less than two months to enter the labor market ${ }^{(15)}$. Another study carried out with graduates of the University of Santo Amaro / SP revealed that, in less than three months, $70 \%$ of their nurses were already employed ${ }^{(16)}$.

It is possible to relate the availability of workforce of nurses in search of employment with studies on youth unemployment. In analyzing the placement of young people in the labor market in Brazil, it is worth considering that this insertion does not fail to express, directly or indirectly, the previous conditions of family life, related to race, geographic origin, urban or rural environment, as well as the basis socioeconomic ${ }^{(17)}$.

The employers' managers interviewed reinforced the reality of the search for employment by young nurses, as they report having a large number of nurses' curricula that are searched daily by the institutions in the state. The managers also identified the search for employment as a preceptor / practical field teacher, governed by temporary work contracts in technical or higher education institutions.

In the NB, the configuration of the nurses' labor market follows a logic of reduction or suppression of labor rights, resulting from the dissemination of forms of insertion in the labor market, replacing wage labor and the protections associated with it. The result is a shift from the pattern of the composition of the mostly paid labor force to precarious work.

Temporary work, temporary work, is part of the strategy of flexibilization of health work, registered in the literature and that in industrialized countries has resulted in job insecurity and increased turnover of health care workers ${ }^{(18)}$. Among these consequences, a study carried out in Canada shows that a major driver for the Canadian nurses to migrate to work in the USA was the lack of work for Integral Time (TI) in the country ${ }^{(19)}$.

In the scenario of health spending reduction, there was a reduction in the workforce of nurses in Canada ${ }^{(20)}$. Several factors were identified as determinants of the reduction in the number of nurses in the market: layoffs at times of labor cost reduction; nurses' retirement; death; invalidity; reduction of working hours; in addition to changes in Fixed-Term Contract (CTD) Contract of Indeterminate Time (CIT).

Considering the various changes in the contractual form of the nurses, a study in Norway showed that the work force of these professionals is carried out predominantly by casual work, which represented, in the year of the research, more than $90 \%$ of contracts of the nurses in the country ${ }^{(21)}$.

The severity of the indication for a job shows in marked colors how vulnerable the population is to the health services, since nurses may not have the qualification expected to provide care. This situation can generate damages to the population and also to the profession, because its visibility is compromised by actions that do not result in safe practices and of quality.
The tendency of the indication for the employment is not something present only in the $\mathrm{RN}$; it was found in a study in the southeast region of Brazil that the indication for a vacancy corresponds to $60 \%$ in the possibility of nurses accessing the labor market in São Paulo(15).

When analyzing the conformations of employment and the outcome on unemployment for nurses, it should be noted that the greatest difficulties of insertion in the labor market in nursing are perceived more pronounced by young people than for nurses with more age and time service in the area. In a study that analyzed the characteristics of employment and the projected workforce in Israel, it was found that the probability of finding and remaining in employment, considering the age group, is five times higher for nurses with a range age between $34-44$ years than among young people aged $24-34$ years $^{(22)}$.

This difficulty of insertion of young people in the labor market contributes to 'unemployment through discouragement, that is, nurses stop acting or seek employment in the area in which they were trained'. Research on trends in the nurses market has shown several reasons why these professionals leave the labor market in the area: search for better salaries outside the health sector; the choice to take on domestic and family responsibilities; the poor working conditions; the greater demands of working environments in the area, resulting in increased workloads and professional exhaustion ${ }^{(23)}$.

The shortage of nurses in the NB is marked by the dichotomy between the need for specialists and the presence of specialists who are unable to take up the jobs, since in addition to the specialization courses in the area they did not meet the requirements for the market, it concerns the practical deepening aspect, which guarantees safety to nurses and employers, these professionals available to the market are the result of a contingent of graduates with various weaknesses in the previous training.

Analyzing the situation of the shortage of nurses on the European continent, many European Union (EU) countries, such as Greece, Ireland, Portugal and Spain, had economic restrictions with very alarming cost containment, which influenced the reduction of personnel and jobs in the sector public. The European Federation of Nurses (FEN) points out that, in addition to the reduction in the number of staff, in many European countries the rates of remuneration of nurses have been frozen or reduced, and labor rights and staff numbers have been reduced ${ }^{(9)}$.

In the current scenario of the labor market for nurses in the $\mathrm{NB}$, it is also worth noting that one of the trends observed in managers 'speeches is the existence of a nurses' cooperative that aims to absorb professionals as self-employed for professional practice. On the one hand, it is observed that this form of insertion in the labor market of nurses is a possibility to start in the professional activity; on the other, may be a form of precariousness, depending on the relationships established within the cooperative.

In the NB, it was verified that it is still a space for the insertion of nurses, since there is only a population demand for care in the state and presents few contingents of cooperative professionals. However, the emblematic marks of the contradiction in the labor market scenario of nurses permeated by the cooperative are present, on the one hand, on the one hand, the claim of labor 
law and access to health universally in accordance with the SUS and, on the other hand, the possibility of legislating on their own right as an autonomous worker.

\section{FINAL CONSIDERATIONS}

The political-institutional scenario that allowed the expansion of the installation of private companies in the training of a large number of nurses, associated to the non-expansion of jobs for this professional category, resulted in a negative impact on the profession, with regard to the access to employment. In the midst of a shortage of qualified professionals to perform care for the people in the NB, there was a contradiction in the surplus of the labor force that graduated from undergraduate nursing courses and that can not be included in the labor market of nurses in the region.

There was also a lack of jobs, lack of training and a practice of market access by indication to the detriment of equal rights criteria to apply for a vacancy and merit-based selection. The market also associates a growth in precarious employment and deficits in working conditions. The work in nursing cooperative appears as a possibility that may constitute a path that strengthens the precariousness or possibility of a more positive character.
It is important to emphasize that the moment when this study was carried out is marked by the context of a policy of not valuing the expansion of jobs for these professionals, especially by the public power, which is responsible for the greater employability of nurses, with highlight the reality still insufficient of population coverage by the FHT and that, therefore, there is no way to indicate how long this trend will be maintained.

In this sense, in the social historical scenario that permeated the context of the study, the favorable and unfavorable aspects on the labor market of nurses are interrelated, in order to synthesize reality.

This study presented specific characteristics of a study of this nature, which does not intend generalizations. However, the results can be transferred to other regions with similar models of professional nursing practice. In addition, the identification of the labor market trends for nurses the NB allowed to affirm that the results provide trends that resemble in part those that exist in the international scenario.

It is recommended the development of other studies, based on the methodological replication used in all regions of Brazil, in order to understand the labor market behavior for nurses related to the social contexts and the priorities adopted for health that interfere with the availability and access to employment for these professionals.

\section{REFERENCES}

1. Oliveira JAS, Pires DEP. A atualidade do debate sobre mercado de trabalho em enfermagem. Rev Enferm UFPE [Internet]. 2014 [cited 2016 Nov 18];11(8):1-5. Available from: https://periodicos.ufpe.br/revistas/revistaenfermagem/article/viewFile/10126/10616

2. Buchan J, Black S. The Impact of Pay Increases on Nurses' Labour Market: A Review of Evidence from Four OECD Countries". OECD Health Working Papers. OECD Publish[Internet]. 2011[cited 2013 Sep 23];57. Available from: http://www.oecd.org/ officialdocuments/publicdisplaydocumentpdf/?cote $=$ DELSA/HEA/WD/HWP(2011)4\&docLanguage $=$ En

3. Buchan J. Nursing shortages and human resource planning. Int J Nurs Stud[Internet]. 2000[cited 2013 Jun 2];31(5):199-207. Available from: http://www.ncbi.nlm.nih.gov/pubmed/7989171

4. Buchan J. International recruitment of nurses: policy and practice in the United Kingdom [Internet]. Health Serv Res [Internet]. 2007[cited 2015 Feb 2];43(2):1321-35. Available from: http://www.ncbi.nlm.nih.gov/pubmed/7989171

5. Dovlo D. Wastage in the health workforce: some perspectives from African countries. Hum Res Health[Internet]. 2005[cited 2015 Feb 7];6(3):1-9. Available from: http://www.human-resources-health.com/content/pdf/1478-4491-3-6.pdf

6. Kingma M. Nurses on the move: migration and the global health care economy[Internet]. Ithaca, NY: Cornell University Press. 2016[cited 2016 Nov 30]. Available from: http://www.cornellpress.cornell.edu/book/?GCOI = 80140100754200

7. Antunes R. Adeus ao trabalho? ensaio sobre as metamorfoses e a centralidade do mundo do trabalho. 7. ed. São Paulo: Cortez; 2007.

8. Pires D. Reestruturação produtiva e trabalho em saúde no Brasil. São Paulo: $2^{a}$ ed. Confederação Nacional dos Trabalhadores em Seguridade Social. CUT: Annablume; 2008.

9. Buchan J, O `May F, Dussault G. Nursing workforce policy and the economic crisis: a global overview. J Adv Nurs [Internet]. 2013[cited 2013 Aug 3];45(3):298-307. Available from: http:// www.ncbi.nlm.nih.gov/pubmed/23656542

10. Brasil. Ministério da Saúde. Secretaria de Atenção à Saúde. Departamento de Atenção Básica. Política Nacional de Atenção Básica. Brasília, 2012.

11. Brasil. Ministério da Saúde. Plano de ações estratégicas para o enfrentamento das doenças crônicas não transmissíveis (DCNT) no Brasil 2011-2022 [Internet]. Brasília, 2011[cited 2016 Nov 30]. 160p. Available from: http://bvsms.saude.gov.br/bvs/publicacoes/ plano_acoes_enfrent_dcnt_2011.pdf

12. Brasil. Ministério do Trabalho. Relação Anual de Informações Sociais (RAIS) do Ministério do Trabalho e Emprego [Internet]. Brasília, 2015[cited 2016 Nov 30]. Available from: http://www.rais.gov.br/sitio/index.jsf

13. Minayo MCS. Desafio do conhecimento: pesquisa qualitativa em saúde. São Paulo: 12. ed, 2010. 
14. Bardin L. Análise de conteúdo. São Paulo: Edições 70; 2011.

15. Puschel, VAA, Inácio MP, Pucci PPA. Insertion of USP nursing graduates into the job market: facilities and difficulties. Rev Esc Enferm USP [Internet]. 2009[cited 2013 Aug 5];43(3):535-42. Available from: http://www.scielo.br/pdf/reeusp/v43n3/en_a06v43n3.pdf

16. Sana MC, Santos CE. Inserção no mercado de trabalho dos egressos do curso de graduação em enfermagem da Universidade de Santo Amaro [Internet]. 2003[cited 2014 Dec 3];22(3):255-60. Available from: http://www.scielo.br/pdf/reeusp/v43n3/a06v43n3.pdf

17. Pochmann M. A batalha pelo primeiro emprego: a situação atual e as perspectivas do jovem no mercado de trabalho brasileiro. São Paulo: 2. ed. Publisher Brasil, 2007.

18. Zeytinoglu IU, Denton M, Davies S, Plenderleith JM. Casualized employment and turnover intention: home care workers in Ontario, Canada. Health Policy [Internet]. 2009[cited 2013 Aug 8];91(3):258-68. Available from: http://www.ncbi.nlm.nih.gov/ pubmed/19178976

19. Freeman M, Baumann A, Blythe J, Fisher A, Danesh NA. Migration: a concept analysis from a nursing perspective. J Adv Nurs[Internet]. 2011 [cited 2013 Aug 2];68(4):1176-86. Available from: http://www.ncbi.nlm.nih.gov/pubmed/22044018

20. Alamedine M, Baumann A, Onate K, Deber R. Career transitions of inactive nurses: a registration database analysis (1993-2006). Int J Nurs Stud [Internet]. 2010[cited 2013 Aug 3];48(2):184-92. Available from: http://www.ncbi.nlm.nih.gov/pubmed/20633883

21. Tommaso ML, Strom S, Saether EM. Nurses wanted is the job too harsh or is the wage too low? J Health Economics [Internet]. 2009[cited 2013 Aug 10];28(3):546-53. Available from: http://www.ncbi.nlm.nih.gov/pubmed/19272663

22. Nirel N, Riba S, Reicher S, Toren O. Registered nurses in Israel: workforce employment characteristics and projected supply. Israel J Health Policy Res [Internet]. 2012[cited 2013 Aug 2];11(1):1-9. Available from: http://www.ijhpr.org/content/1/1/11 